\title{
FLUOROMETRIC ASSAY OF TISSUE HISTAMINE
}

\author{
KAZUYOSHI KURAHASHI AND MOTOHATSU FUJIWARA \\ Department of Pharmacology, Faculty of Medicine, Kyoto University, Sakyo-ku, Kyoto
}

Received for publication Octobcr 26, 1968

There have been numerous studies on the distribution of endogenous histamine (1-5). Many mammalian tissues contain large to small amounts of histamine preformed. Amongst them skin, stomach and lung contain extremely high concentration of histamine. These organs are exposed to the outside directly or indirectly and prone to traumatic injury. The tissue level of histamine has been estimated with the bioassay procedure using isolated guinea-pig intestine or uterus. The fluorometric analysis of tissue histamine was devised by Shore et al. (6). The method involves cxtraction of histamine to n-butanol from alkalinized perchloric acid tissue extracts, return of the histamine to an aqueous solution and condensation with o-phthalaldehyde (OPT) to yield a product with strong and stable fluorescence. This fluorometric determination of tissue histamine is simple, precise and sensitive, but inadequate for the analysis of brain histamine because of the presence of interfering substance. Kremzner and Pfeiffer (7) have shown that the major interfering substance, spermidine, is separable from histamine by the use of a phosphorylated cellulose column. After that, Medina and Shore (8) modified the Kremzner and Pfeiffer procedure so as to increase the sensitivity. In the present experiments the Medina and Shore's modification for the fluorometric analysis of tissuc histamine was carefully re-examined for the application to pharmacological studies.

\section{METHODS}

\section{Extraction of tissue histamine to n-butanol}

Brain, lung, heart, kidney and stomach were removed from Wistar rats immediately after killing by decapitation. Following the description of Shore et al. (6), these tissues were

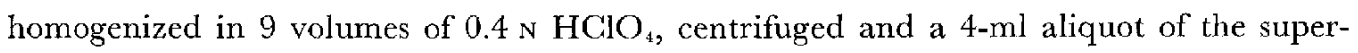
natant fluid was transferred to a $50-\mathrm{ml}$ glass-stoppered shaking tube containing $0.5 \mathrm{ml}$ of $5 \mathrm{~N} \mathrm{NaOH}, 1.5 \mathrm{~g}$ of $\mathrm{NaCl}$ and $10 \mathrm{ml}$ of $\mathrm{n}$-butanol. The tube was shaken for 5 minutes to extract the histamine into the butanol, and after centrifugation the aqueous phase was rcmoved by aspiration. Commercially obtained n-butanol, reagent grade, was washed with $1 \mathrm{~N} \mathrm{HCl}, 1 \mathrm{~N} \mathrm{NaOH}$ and distilled water until the $\mathrm{pH}$ became to 7.0. The water adsorbed in butanol was removed by addition of excess $\mathrm{NaCl}$.

In order to remove residual amounts of histidine extracted to the butanol, the organic phase was shaken for 5 minutes with $5 \mathrm{ml}$ of salt-saturated $0.1 \mathrm{~N} \mathrm{NaOH}$. However, this procedure proved to decrease the recovery of histamine, as described below.

会嵪 和我・藤原 元始 
An $8-\mathrm{ml}$ aliquot of the butanol was transferred to a $50-\mathrm{ml}$ glass-stoppered shaking tube containing $3 \mathrm{ml}$ of $0.1 \mathrm{~N} \mathrm{HCl}$ and $15 \mathrm{ml}$ of n-heptanc. After shaking for 5 minutes the tube was centrifuged, and the organic phase was removed by aspiration. A 2-ml aliquot of the aqueous phase was provided for fluoromctrical assay. n-Heptane was washed with $0.1 \mathrm{~N}$ $\mathrm{HCl}$. The volume of heptane ranging from 15 to $20 \mathrm{ml}$ did not significantly affect the rate of transfer of histamine from the organic to aqueous phase.

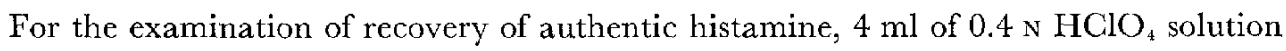
containing a certain amount of histamine dihydrochloride was added with $10 \mathrm{ml}$ of $\mathrm{n}$-butanol, $0.5 \mathrm{ml}$ of $5 \mathrm{~N} \mathrm{NaOH}$ and $1.5 \mathrm{~g}$ of $\mathrm{NaCl}$, and the mixture was shaken for 5 minutes. After centrifugation, a 9-ml aliquot of the butanol was transferred to a shaking tube containing $5 \mathrm{ml}$ of salt-saturated $0.1 \mathrm{~N} \mathrm{NaOH}$. After shaking for 5 minutes the tube was centrifuged. An 8-ml aliquot of the butanol was transferred to another shaking tube containing $3 \mathrm{ml}$ of $0.1 \mathrm{~N} \mathrm{HCl}$ and $15 \mathrm{ml}$ of $\mathrm{n}$-heptane. The tube was shaken for 5 minutes, centrifuged and the supernatant organic phase was removed. Then a 2-ml aliquot of the aqueous phase was transferred to a test tube and $0.4 \mathrm{ml}$ of $1 \mathrm{~N} \mathrm{NaOH}$ was added followed by 0.1 $\mathrm{ml}$ of OPT reagent. After 4 minutes, $0.2 \mathrm{ml}$ of $3 \mathrm{~N} \mathrm{HCl}$ was added. The solution was then transferred to a cuvette and the fluorescence at $450 \mathrm{~m} \mu$ resulting from activation at 356 m $\mu$ was measured with a spectrofluorometer (Hitachi, MPF-2). The recovery of histamine in $\mathrm{HClO}_{4}$ solution ranged from 60 to $70 \%$.

\section{Chromatography using a phosphorylated cellulose column}

Phosphorylated cellulose (Cellex-P, Bio Rad Laboratories) was purified as described by Kremzner and Wilson (9). The cellulose was washed before use with successive portions of $0.1 \mathrm{M} \mathrm{HCl}, 1.0 \mathrm{M} \mathrm{NaCl}, \mathrm{H}_{2} \mathrm{O}, 1.0 \mathrm{M} \mathrm{NaHCO}, \mathrm{H}_{2} \mathrm{O}, 1.0 \mathrm{M} \mathrm{Na} \mathrm{NO}_{3}, \mathrm{H}_{2} \mathrm{O}, 0.1 \mathrm{~m}$ $\mathrm{NaOH}, \mathrm{H}_{2} \mathrm{O}$, ethanol, $\mathrm{H}_{2} \mathrm{O}$ and finally $0.2 \mathrm{~m}$ phosphate buffer, $\mathrm{pH}$ 6.0. Eighty $\mathrm{ml}$ each was uscd for washing $2 \mathrm{~g}$ of the cellulose. The cellulose was then suspended overnight in $0.03 \mathrm{~m}$ phosphate buffer, $\mathrm{pH} 6.0$. The column was prepared in a cold room $(4 \mathrm{C})$ and equilibrated with buffer until the $\mathrm{pH}$ of the effluent was constant and its optical density was essentially zero.

The height of cellulose in a chromatographic column (200 mm length, $6 \mathrm{~mm}$ bore) was $1,2,3$ or $4 \mathrm{~cm}$. A definite amount of histamine dihydrochloride was dissolved in 0.1 $\mathrm{N} \mathrm{HCl}$, then neutralized with an addition of $0.1 \mathrm{~N} \mathrm{NaOH}$ and diluted to $10 \mathrm{ml}$ with $0.03 \mathrm{M}$ phosphate buffer, $\mathrm{pH}$ 6.0. This histamine solution was applied to the column. After

\begin{tabular}{|c|c|c|c|}
\hline $\begin{array}{l}\text { Height of column } \\
(\mathrm{cm})\end{array}$ & Fraction I & Fraction II & Fraction III \\
\hline$-\quad-$ & 97 & -- & $\begin{array}{ccc}- & - & - \\
- & -\end{array}$ \\
\hline 2 & 97 & - & - \\
\hline 3 & 65 & 34 & - \\
\hline 4 & - & 97 & - \\
\hline
\end{tabular}

Each fraction is $5 \cdot \mathrm{ml}$ eluate.

The column bore is $0.6 \mathrm{~cm}$.

$1 \mu \mathrm{g}$ of histamine is applied to column. 
washing the column with $5 \mathrm{ml}$ water the adsorbed histamine was eluted with $5 \mathrm{ml}$ of $0.2 \mathrm{M}$ NaGl. The eluates were analyzed for histamine fluorometrically after condensation with OPT. Recovery of histamine added to the column was 90 to $110 \%$. Table 1 shows a representative result of recovery of histamine in 3 fractions of $5 \mathrm{ml}$ each from 4 columns.

3. Fluorometric assay

In order to decrease the blank reading, commercially obtained OPT was recrystalized from ligroin. By this procedure the melting point of OPT increased from $53^{\circ}$ to $55.2^{\circ} \mathrm{C}$. The OPT was dissolved at a concentration of $1 \%$ in absolute methanol. To estimate histamine in the $\mathrm{NaCl}$ eluate, a 2-ml aliquot containing $0.07 \mu \mathrm{g}$ histaminc per $\mathrm{ml}$ was transferred to a test tube and $0.4 \mathrm{ml}$ of $1 \mathrm{~N} \mathrm{NaOH}$ was added followed by $0.1 \mathrm{ml}$ of OPT reagent. Then $0.2 \mathrm{ml}$ of $3 \mathrm{x} \mathrm{HCl}$ was added. The solution was transferred to a cuvett and the fluorescence at $450 \mathrm{~m} / \mathrm{resulting}$ from activation at $356 \mathrm{~m} /$ (uncorrected) was measured. A maximal reading of fluorescence was obtained at 4 minutes after addition of OPT reagent and a plateau was attained thereafter. The intensity of fluorescence was proportional to histamine concentration ranging from 0.01 to $1.0 \mu \mathrm{g} / \mathrm{ml}$.

\section{Recovery of histamine}

In ordcr to improve a recovery of histamine through the step of butanol extraction, the wash of butanol phase with salt-saturated $0.1 \mathrm{~N} \mathrm{NaOH}$ was omitted. As expected, the omission resulted in a marked improvement of the recovery from 60 to $70 \%$ to 80 to $90 \%$, but possibly at the expense of contamination of residual amounts of histidine which may be present. Therefore, it was examined to what extent histidine does remain in the final $\mathrm{HCl}$ phase.

Histidine in low concentrations produce fluorophore spectrally similar to that of histamine when treated with OPT, but the intensity of fluorescence due to histidine was about $1 / 18$ of that due to histamine in the same concentration of $0.5 \mu \mathrm{g} / \mathrm{ml}$ in $0.2 \mathrm{M} \mathrm{NaCl}$. Twenty $\mu \mathrm{g}$ of histidine was dissolved in $4 \mathrm{ml}$ of $0.4 \mathrm{~N} \mathrm{HClO}_{4}$, then cxtracted into n-butanol and re-extracted into $\mathrm{HCl}$, as described under 1 , but without washing with salt-saturated $\mathrm{NaOH}$. The arbitrary reading of fluorophore resulting from OPT treatment of the aqueous phase was 0.5. This figure would be within experimental errors, compared with a reading of 74 if whole $20 \mu \mathrm{g}$ of histidine could be transferred to the butanol and then to the aqueous phase. The results indicate that any residual amounts of histidine do not interfere in the fluorometric analysis of the butanol extract, even if the washing with salt-saturated $\mathrm{NaOH}$ is omitted.

Under experimental conditions it may be required to give large amounts of histidine exogenously and to separate them from histamine produced. Therefore, the ability of two substances to be adsorbed onto the cellulose column was examincd. It was confirmed that histidine, unlike histamine, was never adsorbed to Cellex-P column and washed out by buffer and water, and that no histidine was detcctable in the first fraction of $0.2 \mathrm{M}$ NaCl eluate. These facts indicate that even if large amounts of histidine are present with histamine and some parts of histidine are transferred to the $\mathrm{HCl}$ phase, the histidine would be completely separated from histamine by the column chromatography. 


\section{RESULTS}

1. Estimation of histamine in brain of rat

Male Wistar rats weighing 150 to $200 \mathrm{~g}$ were used for the determination of brain histamine. Brain was homogenized in 9 volumes of $0.4 \mathrm{~N} \mathrm{HClO}_{4}$, centrifuged, and a $5-\mathrm{ml}$ aliquot of the supernatant fluid was extracted to n-butanol, then returned to $3 \mathrm{ml}$ of $0.1 \mathrm{~N}$ HCl. Washing of the butanol phase with salt-saturated $0.1 \mathrm{~N} \mathrm{NaOH}$ was omitted. Two $\mathrm{ml}$ of the final $0.1 \mathrm{~N} \mathrm{HCl}$ extract was neutralized to $\mathrm{pH} 6.0$ with $0.1 \mathrm{~N} \mathrm{NaOH}$, diluted to $10 \mathrm{ml}$ with $0.03 \mathrm{~m}$ phosphate buffer, and applied to the cellulose column. The adsorbed histamine was eluted with $5 \mathrm{ml}$ of $0.2 \mathrm{M} \mathrm{NaCl}$. A 2-ml aliquot was added with $0.4 \mathrm{ml}$ of $1 \mathrm{~N} \mathrm{NaOH}$, then followed by $0.1 \mathrm{ml}$ of OPT reagent. After 4 minutes, $0.2 \mathrm{ml}$ of $3 \mathrm{~N} \mathrm{HCl}$ was added and the fluorescence was measured at activation $356 \mathrm{~m} \mu$ and fluorescence 450 $\mathrm{m} \mu$.

The major interfering substance in the fluorometric analysis of brain histamine has been reported to be spermidine (7), which is contained in brain more than hundred times as much as histamine. In addition, spermidine produces fluorophore spectrally similar to that of histamine when treated with OPT. A maximal activation was $350 \mathrm{~m} \mu$ and

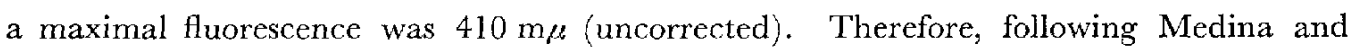
Shore (8) attempts were made to separate histamine from spermidine by the use of a Cellex-P column.

One hundred $\mu \mathrm{g}$ of spermidine was dissolved in $0.1 \mathrm{~N} \mathrm{HCl}$, neutralized to $\mathrm{pH} 6.0$ with $0.1 \mathrm{~N} \mathrm{NaOH}$ and diluted to $10 \mathrm{ml}$ with $0.03 \mathrm{~m}$ phosphate buffer, $\mathrm{pH} 6.0$. The solution was applied to Cellex-P columns $(0.6 \mathrm{~cm}$ bore, 1, 2, 3 or $4 \mathrm{~cm}$ high), and the adsorbed spermidine was cluted with $5 \mathrm{ml}$ of $0.2 \mathrm{M} \mathrm{NaCl}$, then condensed with OPT for fluorometric assay. Five fractions of $5 \mathrm{ml}$ each were collected. Table 2 shows amounts of spermidine eluted through each column. From the results, in conjunction with Table 1, it is concluded that the 2 or $4 \mathrm{~cm}$ high column is suitable for separating histamine from spermidine. With the $2 \mathrm{~cm}$ high column most part of histamine was eluted into the lst fraction, but the amount of spermidine eluted to the 2 nd fraction was so large that even minor deviation of the height of column would result in a contamination with spermidine to the 1 st fraction. The possibility that the histamine fraction might be contaminated with spermidine is much smaller with the $4 \mathrm{~cm}$ high column. Therefore, the $0.6 \times 4 \mathrm{~cm}$ cellulose

\begin{tabular}{|c|c|c|c|c|c|}
\hline \multirow{2}{*}{$\begin{array}{l}\text { Height of column } \\
(\mathrm{cm})\end{array}$} & \multicolumn{5}{|c|}{ Fraction } \\
\hline & I & II & III & IV & $\mathrm{V}$ \\
\hline 1 & 65 & 27.5 & -- & - & - \\
\hline 2 & - & 50.0 & 27.5 & 12.0 & - \\
\hline 3 & -_ & 18.0 & 45.0 & 22.5 & - \\
\hline 4 & - & - & 15.0 & 32.5 & 20.0 \\
\hline
\end{tabular}

Each fraction is 5-ml eluate.

The column bore is $0.6 \mathrm{~cm}$.

$100 \mu \mathrm{g}$ of spermidine is applied to column. 
column was used.

Differential estimation was made with a mixture of known amounts of histamine and spermidine. Solutions containing $50 \mathrm{ng}$ of histamine, $100 \mu \mathrm{g}$ of spermidine, or both in $2 \mathrm{ml}$ of $0.1 \times \mathrm{HCl}$ were neutralized to $\mathrm{pH} 6.0$ with $0.1 \times \mathrm{NaOH}$, diluted to $10 \mathrm{ml}$ with 0.03 м phosphate buffer, and applied to the column. After washing the column with water, histamine and/or spermidine was eluted with $5 \mathrm{ml}$ of $0.2 \mathrm{M} \mathrm{NaCl}$.

The histamine (=x ng) and spermidine $(=\mathrm{y} \mu \mathrm{g})$ in the samples were calculated by solving the equations:

1. $\mathrm{x}+\mathrm{Cy}=\mathrm{A}$

2. $\mathrm{y}+\mathrm{Dx}=\mathrm{B}$

A: fluorometer reading at $356 / 450 \mathrm{~m} \mu$

B: fluorometer reading at $350 / 410 \mathrm{~m} / \mathrm{f}$

C: relative intensity of spermidine fluorescence read at $356 / 450 \mathrm{~m} / \mathrm{s}$ and $350 / 410$ $\mathrm{m} \mu$

D: relative intensity of histamine fluorescence read at $350 / 410 \mathrm{~m} / \mu$ and $356 / 450$ mp!

From the relationship between concentrations of histamine or spermidine and fluorescence intensities at $356 / 450 \mathrm{~m} /$ and $350 / 410 \mathrm{~m} \mu, \mathrm{C}$ and $\mathrm{D}$ were $1 / 3$ and $1 / 2$, respectively. Substituting the constants:

3. $x=\frac{6 \Lambda-2 B}{5}$

4. $y=\frac{6 \mathrm{~B}-3 \mathrm{~A}}{5}$

TABLE 3. Column chromatography of histamine and spermidine.

\begin{tabular}{|c|c|c|c|c|c|c|}
\hline & \multicolumn{2}{|c|}{ Fraction I } & \multicolumn{2}{|c|}{ Fraction $\Pi$} & \multicolumn{2}{|c|}{ Fraction III } \\
\hline & HT & $\mathrm{Sp}$ & HT & $\mathrm{Sp}$ & HT & $\mathrm{Sp}$ \\
\hline HT $0.05 \mathrm{ug}$ & - & - & $0.0425 \mu \mathrm{g}$ & - & - & - \\
\hline HT $0.05 / t g+$ Sp $100_{i}^{\prime \prime g}$ & & - & $0.0525 / \mu \mathrm{g}$ & 一 & - & $10 \mu \mathrm{g}$ \\
\hline $\mathrm{Sp} 100 \mu \mathrm{g}$ & - & - & - & - & - & $8 \mu \mathrm{g}$ \\
\hline
\end{tabular}

Each fraction is $5-\mathrm{ml}$ eluate.

The Cellex-P column is $0.6 \times 4 \mathrm{~cm}$.

Amount of histamine and spermidine is calculated by equations described in text.

HT : Histamine, Sp : Spermidine

The calculated amounts of histamine and spermidine in 3 fractions each from 3 columns are shown in Table 3 . It is evident that spermidine, if exists in large amounts, would not interfer in analysis of histamine. In further experiments, therefore, the Cellex-P column, $0.6 \mathrm{~cm}$ bore $4 \mathrm{~cm}$ high, was used and the 2nd $5-\mathrm{ml}$ eluate was assayed for brain histamine. With other tissues or organs, in which no appreciable amount of spermidine may exist, a $2 \mathrm{~cm}$ high column was used and the 1 st fraction was subjected to the assay of histamine.

The mean content of histamine in the whole brain thus determined was $43.6 \pm 3.6$ 
ng/g, based on 8 observations. This value agrees well with that of Medina and Shore (8).

\section{Histamine content in other organs}

Male Wistar rats weighing 150 to $200 \mathrm{~g}$ were killed, then immediately organs to be analyzed were removed. They were homogenized in $0.4 \mathrm{~N} \mathrm{HClO}_{4}$. Histamine in the acid extract was transferred to n-butanol, returned to an aqueous phase, chromatographied with a Cellex-P column $(0.6 \times 2 \mathrm{~cm})$, and condensed with OPT reagent to form a fluorescent product, as described above. In order to estimate recoveries of histamine, known amounts of histamine dihydrochloride were added to aliquots of the supernatant huid of acid extracts, and the same procedures were followed. In the early stage of experiments, the procedure of washing the butanol phase with salt-saturated $\mathrm{NaOH}$ was also involved. Thus, the recoverics of histamine added to tissue extracts were 64 to $72 \%$, as shown in Table 4. The contents of tissue histamine were correctcd for these factors, and approximated those reported by other investigators.

Table 4. Tissue content and recovery of histamine.

\begin{tabular}{lccc}
\hline Organ & $\begin{array}{c}\text { Content of histamine } \\
(\mu \mathrm{g} / \mathrm{g})\end{array}$ & $\begin{array}{c}\text { Recovery } \\
(\%)\end{array}$ & $\begin{array}{c}\text { Number of } \\
\text { observation }\end{array}$ \\
\cline { 2 - 4 } Lung & $5.4 \pm 0.8$ & $72 \pm 7$ & 11 \\
Heart & $2.4+0.5$ & $66 \pm 4$ & 11 \\
Kidney & $0.25 \pm 0.03$ & $64 \pm 4.7$ & 10 \\
Stomach & $9.1 \pm 0.85$ & $67 \pm 6$ & 18 \\
\hline
\end{tabular}

Histamine is transferred to $\mathrm{n}$-butanol, returned to an aqueous phase, applied to Cellex-P column $(0.6 \times 2 \mathrm{~cm})$. The 1 st $5-\mathrm{ml}$ eluate is assayed spectrofluorometrically. The washing of the butanol phase with salt-saturated $\mathrm{NaOH}$ is involved.

\section{Histamine in stomach}

In succeeding experiments for analyzing stomach histamine, the washing with saltsaturated $\mathrm{NaOH}$ was omitted. The mean content of histamine in stomach after a 24hour starvation was $11.2 \pm 0.7 \mu \mathrm{g} / \mathrm{g}$. When diet was given ad libilum for succeeding 1 hour, and when the 1-hour feeding was followed by additional 4-hour starvation, the values were $11.5 \pm 1.4 \mu \mathrm{g} / \mathrm{g}$ and $10.2 \pm 1.2 \mu \mathrm{g} / \mathrm{g}$, respectively. These results indicate that the histamine level in stomach is not affected by the volume of stomach contents. Histidine at a dose of $100 \mathrm{mg} / \mathrm{kg}$ was given orally to rats starved for 48 hours. The histamine content increased to 14.5 and $12.8 \mu \mathrm{g} / \mathrm{g}$ at 1 and 3 hours, respectively, after administration, which indicate that histidine exogenously administered was taken up by stomach and converted to histamine.

In further experiments, the stomach was divided into the non-glandular (rumen) and glandular (body and antrum) portions. The content of histamine in the body was more than twice as much as that of rumen or antrum. Pylorus-ligated Shay rats and coldexposed restraint rats were prepared as described (10), and histamine was assayed. With the progress of ulceration the content of histamine, particularly in the body of cold-exposed 


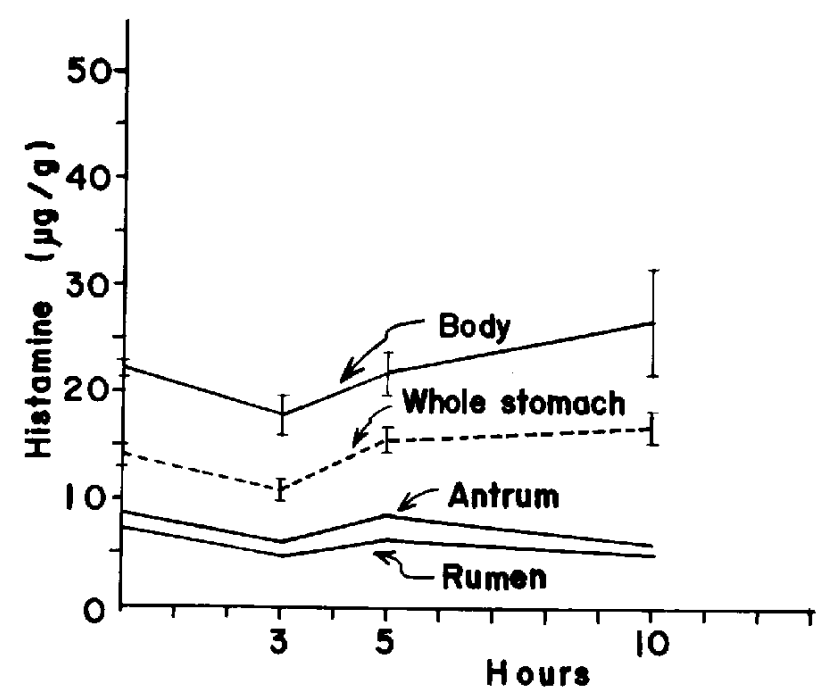

Fig. 1. Histamine content of stomach of Shay rat after ligation of pylorus. Mean and standard error of 3 to 6 observations. The values of whole stomach (dotted line) were calculated from those of three portions; rumen, body, antrum.

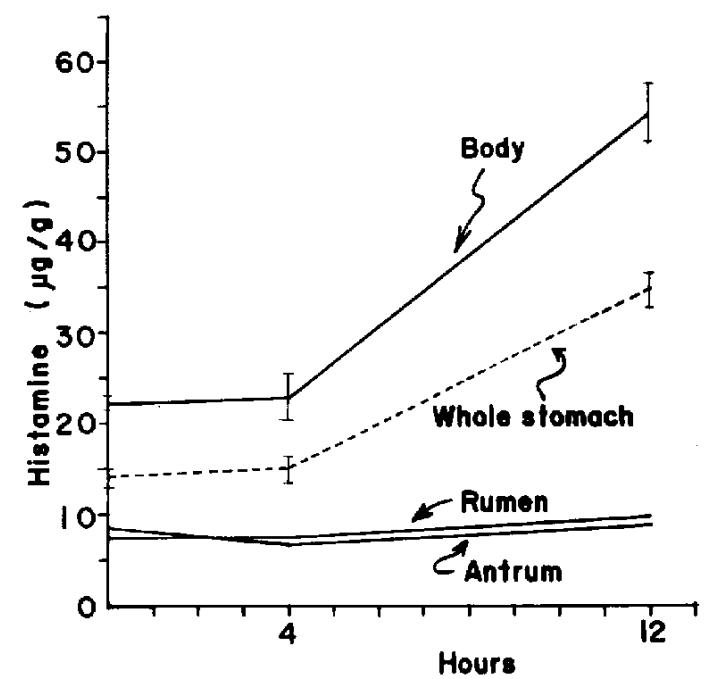

Fig. 2. Histamine content of stomach of cold-exposcd restraint rat. Mean and standard error of 3 to 6 observations. Tho values of whole stomach (dotted line) were calculated from those of three portions; rumen, body, antrum.

restraint rat, increased as shown in Figs. 1 and 2. Calculating the content of histamine in whole stomach based on the values in three portions, the changes of histamine level in the rumen and antrum were masked by those in body where relatively large amounts of histamine were present. 


\section{DISCUSSION}

Several techniques have been employed for the estimation of tissue histamine. . These have been based on the bioassay on isolated guinea-pig organs, or colorimetric assay after trcatment with a diazonium salt (11) or dinitrofluorobenzene $(12,13)$. Shore et al. (6) have devised a simple, specific and sensitive fluorometric method for analysis of tissue histamine. More recently, Medina and Shore $(8\rangle$ have performed regional analysis of histamine in brain using a phosphorylated cellulose column. The present experiments were designed to separate histamine from histidine or spermidinc following the methods of Shore et al. (6) and Medina and Shore (8). It was confirmed that the raeltive intensity of fluorescence of OPT condensation products of histidine and histamine was about $1 / 18$ and that any appreciable amount of histidine did not remain in the butanol phase, even if washing the butanol with salt-saturated $\mathrm{NaOH}$ was omitted. Furthermore, histidine, if any, remaining in the $\mathrm{HCl}$ phase was separable from histamine using the cellulose column. Spermidine is contained in large amounts in brain, produces fluorophore spectrally similar to that of histamine when treated with OPT and thus might interfer in analysis of brain histamine. By the use of cellulose column, $0.6 \times 4 \mathrm{~cm}$, the spermidine was thoroughly separated from histamine. Thus, the omission of washing the butanol phase with saltsaturated $\mathrm{NaOH}$ and the use of phosphorylated cellulose column increased recoveries of tissue histamine with separation from histidine or spermidine, enough to be applicable to pharmacological studies. The ulceration of stomach of cold-stressed restraint rat was prominent in the portion of body, while that of pylorus-ligated Shay rat was in the portion of rumen $(10)$. The relationship between the ulcer formation and histamine level of stomach will be considered in a future report, in conjunction with the level of serotonin.

\section{SUMMARY}

The Shore's fluorometric method for the estimation of histamine in tissues was carefully examined, and the experimental condition for analyzing small amounts of histamine in brain and other organs was described. Tissue histamine was extracted to n-butanol, returned to an aqueous solution, applied to a phosphorylated cellulose column (Cellex-P) followed by elution with $\mathrm{NaCl}$, and condensed with o-phthalaldehyde to yield a fluorescent product. The fluorescence was estimated in a spectrofluorometer. Using a Cellex-P column $(0.6 \times 2$ or $4 \mathrm{~cm})$, histidine and spermidine were thoroughly separated from histamine. The washing of butanol phase with salt-saturated $\mathrm{NaOH}$ was not required for scparation. Concentrations of histamine as low as $0.010 \mu \mathrm{g} / \mathrm{ml}$ could be assayed with a recovery of 80 to $90 \%$. Low level of histamine in brain was analyzed precisely. The method proved to be applicable to routine, pharmacological studies of histamine in stomach and other organs.

\section{REFERENCES}

1) Feldberg, W. A.sd Miles, A.A.: J. Physiol. 120, 205 (1953)

2) Riley, J.F. And West, G.B.: J. Physiol. 120, 528 (1953) 
3) Mota, I., Beraldo, W.T., Ferri, A.G. and Junquerra, L.C.U.: Giba Found. Symposium on Histamine, p. 47, Churchill, London (1956)

4) Yamasaki, H. and Endo, K.: Jap. J. Pharmac. 17, 228 (1967)

5) Vugman, I. and Rocita e Sit.va, M.: Handbuch der Experimentellen Pharmakologie, Vol. XVIII/1, p. 81, Springer-Verlag, Berlin (1966)

6) Shore, P.A., Burkhalter, A. And Cohn, V.H. Jr.: J. Pharmac. exp. Ther. 127, 182 (1959)

7) Kremzaner, L.T. and Preiffer, C.C.: Biochem. Pharmac. 15, 197 (1966)

8) Medina, M. And Shore, P.A.: Binchem. Pharmac. 15, 1627 (1966)

9) Kremzner, L.T. and Wilson, I.B.: J. biol. Chem. 238, 1714 (1963)

10) Muryobayashi, T., Fujiwara, M. and Shimamoto, K.: Jap. J. Pharmac. 18, 299 (1968)

11) Rosenthal, S.M. And Tabor, H.: J. Pharmac. exp. Ther. 92, 425 (1948)

12) Molntire, F.C., Wiite, F.B. and Sprovll, M.: Arch. Biochem. 29, 376 (1950)

13) Lowry, O.H., Graham, H.T., Harris, F.B., Priebot, M.K., Marks, A.R. nnt Bregman, R.U.: J. Pharmac. exp. Ther. 112, 116 (1954) 